\title{
Descriptive Legal Theory
}

\author{
Dr Julie Dickson \\ Fellow and Senior Law Tutor, Somerville College, Oxford \\ Associate Professor, Faculty of Law, University of Oxford \\ julie.dickson@law.ox.ac.uk \\ https://www.law.ox.ac.uk/people/julie-dickson \\ http://www.some.ox.ac.uk/people/julie-dickson/
}

\section{[AUTHOR ACCEPTED MANUSCRIPT VERSION]}

\section{Introduction}

A tradition of thought in legal theory woven through the work of Jeremy Bentham and John Austin in the nineteenth century, and that of Hans Kelsen and H.L.A. Hart in the twentieth, contends that it is possible to construct successful theories of law which are - in a certain sense discussed more fully below - descriptive in character. According to this approach, it is an important task of legal theory to identify and explain what law is, and this project can be undertaken relatively independently of, and prior to, attempting to morally evaluate or justify law. Bentham, Austin, Kelsen and Hart also share the methodological goal of attempting to explain the nature of law. That is to say, their theories attempt to identify and adequately explain law's essential properties: those features of law which make it into what it is. These theorists, then, are seeking a descriptive account of the nature of law, and believe that it is possible to answer questions such as: Is it in the nature of law that it can be identified purely by reference to social facts? Is coercion an essential feature of law?, and Do legal systems necessarily claim authority over their subjects?, relatively independently of, and prior to, answering questions such as: Does that which we identify as law possess any moral qualities? Can the exercise of coercion via law be justified?, and Under what conditions do legal systems possess legitimate authority over their subjects?

Although this methodological position is a long-standing one, a renewal of interest in methodological questions in legal theory in recent times has seen some contemporary jurisprudential scholars attempt to cast doubt upon the possibility and/or usefulness of descriptive accounts of the 
nature of law. Those harbouring such doubts might claim any or all of the following: (i) that it is impossible to delineate those features of law a given theory will focus on without making evaluative judgements concerning which are the most important or significant aspects of law to explain; (ii) that it is impossible adequately to explain certain features of law without making moral value judgements regarding law's moral worth or justifiability; (iii) that it is necessary to resort to moral or political argumentation concerning the consequences of espousing one view of law as opposed to another in order to adjudicate between rival legal theories. The following discussion attempts to throw more light on these doubts, and to consider possible responses to them, in the service of further illuminating the character and aims of descriptive legal theory.

\section{Descriptive Legal Theory: Challenges and Responses}

A simple - although ultimately misleading - account of descriptive legal theory might characterise it as the view that a legal theorist can accurately identify and adequately explain the nature of law without making any value judgements whatsoever, thus simply describing law as it is. This is sometimes - albeit mistakenly - taken to be the view of descriptive legal theory endorsed by H.L.A. Hart in the 'Postscript' to the second edition of The Concept of Law where Hart contrasts his own, "general and descriptive" legal theory with Ronald Dworkin's, "in part evaluative and justificatory" conception of jurisprudence (Hart 1994, 239-240). In different ways, the three challenges to this simple account discussed below claim that it is impossible for legal theory to be value-free. In considering these challenges, and surveying some contemporary responses to them, a revised and more nuanced account of the character and aims of descriptive legal theory begins to emerge.

\section{The role of evaluations of importance and significance in constructing theories of law}

One possible challenge to the simple account of descriptive legal theory claims that to construct a successful theory of law it is necessary to make value judgements regarding the importance and significance of certain features of law and understandings about law. There may be two aspects to this challenge. First, it may be claimed that constructing a theory of anything requires one to make evaluative judgements sifting the important from the unimportant, the significant from the banal, in order to present a theoretical account rather than a mere miscellany of information (see e.g. Finnis 1980 , ch.1, 17). Secondly, it may further be claimed that in the case of theories of law, legal theorists making evaluations concerning the important and significant features of their subject matter must 
be guided by, and must be appropriately sensitive to, what is already regarded as important and significant about law by those who create, administer, and are guided by it (see e.g. Finnis 1980, ch.1, 12; Perry 1998; Postema 1998, section I). This second claim is motivated by the idea that law is a concept which is used by people to understand themselves and their practices (on this point see Raz 1994, at 237; Dickson 2001, 39-44; Dickson 2015, section 3) and is hence what Leiter (2003, 40-43) refers to as a hermeneutic concept (this theme also runs throughout Hart 1961 \& 1994).

Despite these points sometimes being presented as challenges to what I have referred to above as the 'simple account' of descriptive legal theory, there may in fact be none who would deny them. Contemporary legal theorists who contend that it is an important task of legal theory to identify and explain what law is, and maintain that this project can be undertaken relatively independently of, and prior to, attempting to morally evaluate and justify law, have explicitly endorsed the points outlined above concerning the ways in which certain kinds of evaluative judgements must necessarily enter into an explanatorily adequate theory of law (see e.g. Raz 1994, 235-7, 300-301; Waluchow 1994, 19-30; Green 1996 section IV; Coleman 2001, chs. 11 \& 12; Dickson 2001, chs. 2 \& 3, Dickson 2004, section II, Dickson 2015, section 3; Marmor, 2001, 153-9). Indeed, Hart himself, although insisting upon the possibility and usefulness of a "general and descriptive" approach to legal theory (Hart 1994, 239-40), also recognises that a legal theorist's analysis, “...will be guided by judgements, often controversial, of what is important and will therefore reflect such meta-theoretic values and not be neutral between all values." (Hart 1987, 39). Hart elaborates further on this point when he explains that his own approach to legal theory:

“... wouldn't be morally evaluative. ... it's evaluative in a sense that you pick out features of the complex activity, not because it justifies it morally, but because these would be relevant to among other questions what moral questions you ask. But it doesn't give the answer. Whereas Dworkin is saying any worthwhile jurisprudence is a blend of description and moral evaluation - it's got to show the law in its best light. Why not show it in the worst light?" (Sugarman 2005, at 288).

This begins to reveal the significant inadequacy of the simple account: if no one is claiming that legal theory can be entirely value-free, and if any such claim, were it to be made, would necessarily be false, then there is little point characterising descriptive legal theory in the way the simple account does. 


\section{The claim that moral evaluation is essential for explanatorily adequate legal theory}

A second challenge to 'descriptive' legal theory is the contention that in order to construct an explanatorily adequate account of law, it is necessary for a legal theorist to engage in moral evaluation of law, and to reach conclusions regarding its moral worth and the conditions under which it is morally justified. In different forms, this challenge features prominently in the work of both John Finnis (Finnis 1980, especially ch. 1; Finnis 2003) and Ronald Dworkin (Dworkin, 1986, passim; Dworkin 2004).

As was noted in section II.1 above, Finnis claims that in order to construct an explanatorily adequate theory of law, a legal theorist must evaluate which are the important and significant features of the subject-matter to be explained, and in so doing, must pay appropriate attention to beliefs about and attitudes towards law held by those living under and being guided by it. Finnis further contends that some of those attitudes towards law are more important and significant than others, and that it falls to legal theory to discriminate between them and to characterise law from the 'central case' viewpoint from which we can explain why law came into being, and why we strive to maintain its existence. According to Finnis, this point of view - which he also characterises as the point of view of the practically reasonable man - is the point of view of someone who appreciates the moral value of the law, and the way in which its unique properties facilitate the realisation of certain moral goods in our lives, hence creating a presumptive moral obligation to obey it. Legal theorists must thus take a stance on the moral value and purpose of law, and on when and under what conditions it creates a presumptive moral obligation to obey it, in order to characterise law adequately from what Finnis claims is the appropriate legal theoretical point of view (Finnis 1980, especially ch. 1; Finnis 2003).

Dworkin (1986, passim) contends that to understand law we must constructively interpret it, i.e. we must seek to put our community's legal practices in their best light in terms of the value, point or purpose they are trying to serve. In Law's Empire, Dworkin gives this point as being to police and justify the imposition of state collective force (Dworkin 1986, 93. For other of Dworkin's views on methodology, and in particular his discussion of the role of the value of legality in understanding law, see Dworkin 2004; Dworkin 2006, especially chs. 2, 6, 7 and 8). For Dworkin, then, legal theorists and indeed anyone seeking to know what law is must engage in an interpretive process which requires them to make moral and political value judgements in ascertaining which propositions of law are 
true: such propositions will be true when they flow from interpretive argument putting a given community's legal practices in their best moral and political light in terms of their ability to justify the imposition of collective force.

As was noted in section II.1, several contemporary legal theorists who contend that it is an important task of legal theory to identify and explain what law is, and maintain that this project can be undertaken relatively independently of, and prior to, attempts to morally evaluate and justify law, do not endorse the further and distinct contention that legal theory can be entirely value-free. However, some of those theorists do reject those aspects of Finnis' and Dworkin's methodological standpoints outlined above. This methodological approach - which holds that understanding the nature of law requires us to make evaluative judgements, but not necessarily morally evaluative judgements concerning the law's moral worth or justifiability - underpins some of the most important contributions to contemporary legal positivism: for example, works by Raz (1985, 732-5; 1994, 235 7, 300-301); Coleman (2001, chs. 11 \& 12); Marmor (2001, 153-9); Waluchow (1994, 19-30). In these works, the theorists concerned draw on an evaluative-but-not-morally-evaluative methodological position in order to support and defend their own first-order theories of the nature of law. For example, in laying the groundwork for arguments in favour of his own brand of inclusive legal positivism, Waluchow (1994, 19-30) points out that a legal theorist makes evaluative judgements in establishing that a particular feature of law, such as its use of coercion, is important to explain, and is relevant to any eventual moral evaluation of law, without yet knowing, and without attempting to judge whether, that feature of law is morally good or justified. Waluchow thus argues in favour of the tenability of a methodological position he refers to as "value-relevant, descriptive-explanatory" theory (Waluchow 1994, at 22). As was noted at the close of section II.1 above, HLA Hart should also be regarded as a proponent of such a methodological stance.

In works discussing jurisprudential methodology as a topic in its own right, rather than drawing on a particular methodological position in order to support the author's own account of the nature of law, Dickson $(2001,2004,2015)$ claims that in order to construct successful theories of law, legal theorists must make value judgements concerning which are the important and significant features of law to explain which are sufficiently sensitive to that which is already considered important and significant about law by those living under and guiding their conduct by it. Dickson terms these 'indirectly evaluative' judgements, and contends that legal theorists can make them without taking a stance on the moral value or goodness of that which they are evaluating as 
important or significant (see Dickson, 2001, ch. 3; 2004, section II.A; 2015, section 3). On this view, a legal theorist's 'indirectly evaluative' judgements that a given feature of law - such as law's claim to possess moral authority - is important to explain can be supported by the fact that the feature of law in question plays a central role in the self-understandings and practical concerns of those living under law (e.g. law's claim to possess moral authority may be important to explain because it will result in law applying itself to those living under it, and potentially subjecting them to coercive sanctions as a result, whether or not it is justified in so doing), rather than by a morally or 'directly evaluative' judgement such as that this feature of law is important to explain because it allows law to perform a morally valuable function. Dickson does not deny the importance of asking and attempting to answer morally or directly evaluative questions such as whether law is morally valuable or justified, and whether and under what conditions there is a moral obligation to obey it, but, she contends, these questions can and should be tackled once we have a non-morally evaluative account of the nature of law in respect of which we can address them (Dickson 2001, especially chs. 3 and 8). In recent (Dickson 2015) and forthcoming (Dickson, forthcoming 2018) work, Dickson terms this position 'indirectly evaluative legal philosophy', and argues that this methodological position rightly approaches law with an "attitude of due wariness" (Dickson 2015, at 227-228), and allows us to understand its nature without inappropriately venerating it, and in a manner which will best facilitate law's eventual accurate moral evaluation (Dickson 2015, especially section 3). Dickson strongly emphasizes the ties that exist between indirectly evaluative legal philosophy, and legal philosophy which engages in moral evaluation and criticism of law, and contends that the former, properly done, can successfully facilitate and enhance the character of the latter (Dickson 2015, section 3; Dickson, forthcoming 2018, passim).

\section{Practical-Political or Beneficial Moral Consequences Arguments}

A third potential challenge to descriptive legal theory comes from those theorists who contend that in order to adjudicate between rival accounts of law, we should engage in what are variously referred to as 'practical-political' (Murphy 2001) or 'beneficial moral consequences' arguments (Dickson 2001 ch. 5 uses this latter term although she herself rejects the validity of such arguments). Legal theorists advocating this approach contend that practical consequences of a moral and/or political nature flow from adopting one view of law over another and that in arguing in favour of a given theory of law we should evaluate what those consequences might be, and should decide upon which view of law to 
espouse accordingly. For example, Murphy (2001) claims that unless we adopt a view of law which is committed to an exclusive legal positivist interpretation of the social thesis - the contention that the existence and content of the law of a given legal system depends exclusively on matters of social fact - then we risk adverse moral and political consequences in the form of a lack of societal critical evaluation of the law, and an over-ready acceptance that because something is law it must be morally just. Variations on this kind of argument may also be found in MacCormick 1985 and Guest 1996.

Practical-political or beneficial moral consequences arguments appear to challenge descriptive legal theory's claim that it is possible to identify and explain what law is without engaging in moral value judgements. Some legal theorists (see e.g. Raz 1979, at 41-2; Soper 1987; Waluchow 1994 at 86-98; Dickson 2001, ch. 5) have further objected to this kind of argument on the ground that it appears to involve an element of wishful thinking, because the central gist of such arguments seems to be that, as beneficial moral and/or political consequences would follow if law had certain properties, therefore we should understand law as having those properties. Murphy (2001, at 389) responds to this objection with the counter-claim that a legal theorist is not indulging in wishful thinking if there is - at least in respect of some features of law - no fact of the matter that the theorist is ignoring in deploying practical-political arguments. This type of argument thus also appears to run counter to the aims of descriptive legal theory in that it seems to deny, at least in respect of some of law's properties, that law has a nature to be identified and explained, thus leaving room for us to choose which view of law to espouse based on the beneficial moral and/or political consequences which might ensue as a result.

Frederick Schauer (2005) takes a slightly different view of the role of practical-political or beneficial moral consequences arguments in legal theory, claiming that they are important and perhaps essential for theorists engaging in prescriptive legal theory. Such theorists offer arguments regarding which concept of law ought to be espoused by a given society, and aim to change present understandings of law, based partly on the beneficial moral and political consequences which will ensue as a result. In Schauer's view (as stated in Schauer 2005), this task of prescribing what our concept of law ought to be, is distinct from, but compatible with, descriptive legal theory's aim of characterising the concept of law as it is presently understood in a given society.

\section{III. 'Descriptive' Legal Theory Revised: Some Conclusions}


An important tradition of thought in legal theory contends that it is possible and valuable to identify and explain the nature of law relatively independently of, and prior to, attempting to morally evaluate or justify law. This methodological approach flows through the work of Bentham, Austin, Kelsen and Hart, and contemporary legal theorists such as Raz, Coleman, Marmor, Waluchow and Dickson are its present-day intellectual inheritors. However, care must be taken in using the term 'descriptive' in characterising this position, for these theorists recognise and indeed embrace the idea that certain kinds of evaluative judgements are indispensable in constructing successful accounts of the nature of law. This approach is better characterised as recognising that legal theory cannot and should not be value-free, but as denying that legal theorists need make judgements concerning the moral value and moral justifiability of law in order to understand its nature. According to this evaluative-but-not-morally-evaluative methodological standpoint, questions regarding law's moral value and justifiability are vitally important, and are a central part of jurisprudential inquiry, but they fall to be considered after we have constructed a non-morally evaluative account of the nature of law.

\section{Related Entries:}

The Concept of Law

Hermeneutical Legal Theory

Legal Positivism

Legal Theory: Types and Purposes

Meta-theory in Jurisprudence

The Nature of Law

\section{Bibliography:}

Coleman, J.L., The Practice of Principle: In Defence of a Pragmatist Approach to Legal Theory (Oxford University Press, Oxford 2001).

Dickson, J., Evaluation and Legal Theory (Hart Publishing, Oxford 2001).

Dickson, J., 'Methodology in Jurisprudence: A Critical Survey', 10 Legal Theory, 117 (2004).

Dickson, J., 'Ours is a Broad Church: Indirectly Evaluative Legal Philosophy as a Facet of Jurisprudential Inquiry', 6:2 Jurisprudence, 207-23 (2015) 
Dickson, J., Elucidating Law: The Philosophy of Legal Philosophy, (forthcoming 2018, under contract with Oxford University Press, Oxford).

Dworkin, R., Law's Empire (Fontana Press, London 1986, and reprinted 1998 by Hart Publishing, Oxford).

Dworkin, R., 'Hart's Postscript and the Character of Political Philosophy', 24 Oxford Journal of Legal Studies (2004), 1-37.

Dworkin, R., Justice in Robes, (Harvard University Press, Cambridge, Mass., 2006).

Finnis, J., Natural Law and Natural Rights, (Clarendon Press, Oxford 1980).

Finnis, J., 'Law and What I Truly Should Decide', 48 American Journal of Jurisprudence , 107 (2003).

Green, L., 'The Concept of Law Revisited', 94 Michigan Law Review (1996), 1687.

Guest, S., 'Two Strands in Hart's Theory of Law: A Comment on the Postscript to Hart's The Concept of Law', in S. Guest (ed.), Positivism Today (Dartmouth Publishing, Aldershot 1996).

Hart, H.L.A., 'Comment' in R. Gavison (ed.), Issues in Contemporary Legal Philosophy: The Influence of H.L.A. Hart (Clarendon Press, Oxford 1987).

Hart, H.L.A., The Concept of Law, 2nd edition, with a Postscript edited by P.A. Bulloch \& J. Raz (Clarendon Press, Oxford 1994 (first edition 1961)).

Leiter, B., 'Beyond the Hart/Dworkin Debate: The Methodology Problem in Jurisprudence', 48 American Journal of Jurisprudence, 17 (2003).

MacCormick, N., 'A Moralistic Case for A-Moralistic Law', 20 Valparaiso Law Review (1985), 1.

Marmor, A., Positive Law and Objective Values (Clarendon Press, Oxford 2001).

Murphy, L., 'The Political Question of the Concept of Law' in J.L. Coleman (ed.), Hart's Postscript: Essays on the Postscript to The Concept of Law (Oxford University Press 2001).

Perry, S.R., 'Hart's Methodological Positivism', 4 Legal Theory (1998), 427, and reprinted in J.L. Coleman (ed.), Hart's Postscript: Essays on the Postscript to The Concept of Law (Oxford University Press 2001).

Postema, G., 'Jurisprudence as Practical Philosophy' in 4 Legal Theory 329 (1998).

Raz, J., The Authority of Law (Clarendon Press, Oxford 1979).

Raz, J., 'The Morality of Obedience', 83 Michigan Law Review (1985), 732.

Raz, J. Ethics in the Public Domain (Clarendon Press, Oxford 1994).

Schauer, F., 'The Social Construction of The Concept of Law: A Reply to Julie Dickson', 25 Oxford Journal of Legal Studies (2005), 493. 
Soper, P., 'Choosing a Legal Theory on Moral Grounds', in J.L. Coleman \& E.F. Paul (eds.), Philosophy and Law (Blackwell, Oxford 1987).

Stavropoulos, N., 'Interpretivist Theories of Law', The Stanford Encyclopaedia of Philosophy (Winter 2003 Edition), E. Zalta (ed.),

URL = http://plato.stanford.edu/archives/win2003/entries/law-interpretivist/

Sugarman, D., Words of HLA Hart, in D Sugarman, 'Hart Interviewed: H.L.A. Hart in Conversation with David Sugarman', 32 Journal of Law and Society (2005), 267-293.

Waluchow, W., Inclusive Legal Positivism (Clarendon Press, Oxford 1994). 